\title{
Stress memory responses and seed priming correlate with drought tolerance in plants: an overview
}

\author{
Xun Liu $^{1,2} \cdot$ Wenli Quan ${ }^{1,3} \cdot$ Dorothea Bartels $^{1}$ (I) \\ Received: 26 September 2021 / Accepted: 8 January 2022 / Published online: 23 January 2022 \\ (c) The Author(s) 2022
}

\begin{abstract}
Main conclusion Environmental-friendly techniques based on plant stress memory, cross-stress tolerance, and seed priming help sustainable agriculture by mitigating negative effects of dehydration stress.
\end{abstract}

\begin{abstract}
The frequently uneven rainfall distribution caused by global warming will lead to more irregular and multiple abiotic stresses, such as heat stress, dehydration stress, cold stress or the combination of these stresses. Dehydration stress is one of the major environmental factors affecting the survival rate and productivity of plants. Hence, there is an urgent need to develop improved resilient varieties. Presently, technologies based on plant stress memory, cross-stress tolerance and priming of seeds represent fruitful and promising areas of future research and applied agricultural science. In this review, we will provide an overview of plant drought stress memory from physiological, biochemical, molecular and epigenetic perspectives. Drought priming-induced cross-stress tolerance to cold and heat stress will be discussed and the application of seed priming will be illustrated for different species.
\end{abstract}

Keywords Cross-stress tolerance $\cdot$ Dehydration stress $\cdot$ Drought priming $\cdot$ Drought tolerance $\cdot$ Epigenetic perspective . Plant stress memory $\cdot$ Seed priming

\section{Introduction}

Dehydration stress is one of the major environmental factors affecting the survival rate and productivity of plants. Dehydration leads to low water availability and adversely affects food security (Abdelraheem et al. 2019; Mahmood et al. 2020). In plants, the amount of water loss by transpiration exceeds the amount of water up-take via roots, giving rise to dehydration stress (Chawla 2019). Water deficit

Communicated by Gerhard Leubner.

Dorothea Bartels

dbartels@uni-bonn.de

1 Institute of Molecular Physiology and Biotechnology of Plants (IMBIO), University of Bonn, Kirschallee 1, 53115 Bonn, Germany

2 College of Bioengineering, Sichuan University of Science \& Engineering, Zigong 643000, China

3 Key Laboratory for Quality Control of Characteristic Fruits and Vegetables of Hubei Province, College of Life Science and Technology, Hubei Engineering University, Xiaogan 432000, Hubei, China causes cellular dehydration, accumulation of reactive oxygen species (ROS), cell death, and ultimately affects metabolism and growth (Farooq et al. 2009). To overcome this unfavorable condition, dehydration-tolerant crops have been developed through breeding programmes or transgenic technologies or genome modification approaches (Mahmood et al. 2020). More recently, potential solutions based on plant immune systems, including plant stress memory, cross-stress tolerance, and seed priming have emerged as efficient and favorable approaches for enhancing plant tolerance and crop yield without employing genetic engineering technologies (Wojtyla et al. 2020). Therefore, a better understanding of the mechanisms of these approaches is important for biotechnological innovation of plant resilience.

Due to frequent climatic changes and extreme conditions occurring recently plants are likely to be exposed to multiple abiotic stresses during their whole life span, instead of single stress events (Li and Liu 2016). To survive stress and to adapt to harsh environments, plants have to find suitable ways to respond to recurrent stresses. It has been observed that pre-exposure to a mild biotic or abiotic stress can prepare plants for subsequent severe stress exposures 
(Walter et al. 2011; Ramírez et al. 2015). This phenomenon is referred to as "plant priming", which is considered as a potential way to improve stress tolerance, and it is related to "plant stress memory" (Bruce et al. 2007). The expression "plant priming" is generally used in the context of biotic stresses and application of chemicals for the first exposure, while the similar process is termed "hardening" or "acclimation" in the context of abiotic stress (Sinclair and Roberts 2005; Chen et al. 2012; Hilker et al. 2016; Savvides et al. 2016). The concept of stress memory represents an intrinsic response to repeated stress events (Avramova 2015). Many efforts have been made to explore the mechanisms of stress memory in different plant species which have encountered diverse stresses (Ramírez et al. 2015; Walter et al. 2011; Wang et al. 2014, 2015; Shukla et al. 2015; Sun et al. 2018). The results show that stress memory is involved in modifications at different levels, including morphological, physiological, transcriptional, translational, and epigenetic levels (Kinoshita and Seki 2014; Sun et al. 2018).

Cross-stress tolerance represents the tolerance to a second strong stress which differs from the first stress after experiencing a primary mild stress. Cross-stress tolerance is achieved by the activation of multiple stress signaling pathways during the first stress encounter, and these activated pathways work synergistically or antagonistically during subsequent stress events (Hossain et al. 2018). It has been reported that the cross-stress tolerance gained from a single stressor can lead to the tolerance of multiple stresses (Herms and Mattson 1992; Li and Gong 2011; Ferreira-Silva et al. 2011; Zhang et al. 2013; Li et al. 2014; Faralli et al. 2015). Cross-stress tolerance provides the possibility to understand common signaling molecules and to compare individual responses during different stresses (Hossain et al. 2016).

In addition to priming on the whole plant level, memory and cross-stress tolerance, the priming of seeds is also pivotal in managing stressful conditions. Seed priming is a treatment applied before sowing during seed imbibition (Sen and Puthur 2020). Seed imbibition involves three stages of seed development: rapid water uptake, saturation of water uptake, and water uptake together with the onset of cell division and growth. The second stage appears to be the critical stage for seed priming (Cheng et al. 2017). Seed imbibition is a complex physiological and biochemical process, and many metabolic processes take place during the second stage, including restoring of mitochondrial and cellular integrity, mobilizing of stored energy, synthesis of RNAs and proteins (He and Yang 2013). Seed priming is a crucial technology for uniformity of germination and seedling establishment under adverse environmental conditions.

This review summarizes the physiochemical and molecular perspectives of plant stress memory, and illustrates how cross-stress tolerance and seed priming can contribute to stress tolerance.

\section{Physiological and biochemical perspectives of drought stress memory}

To optimize growth and reproduction in frequently changing environments, plants may adjust their physiology to give rise to structural and physiological adaptations (FletaSoriano and Munné-Bosch 2016). Many plant species display a drought stress memory on the physiological and biochemical level, to minimize water loss, to obtain ROS homeostasis, alterations of photosynthetic rates, variations of phytohormone contents, or changes in biomass (Ding et al. 2014; Ramírez et al. 2015; Wang et al. 2015; Li et al. 2016; Abdallah et al. 2017; Neves et al. 2017).

The rate of water loss from plant leaves has been proposed as a basic parameter to reflect the growth conditions of plants. In Arabidopsis thaliana plants, which underwent a drought stress treatment, the stomata were still partially closed during the well-watered recovery period, which is beneficial for water conservation if exposed to a subsequent dehydration stress (Virlouvet and Fromm 2015). A repetitive dehydration/rehydration system was developed by Ding et al. (2012) to determine whether A thaliana plants retain a drought stress memory. A significant lower water loss rate was observed during the second, third and fourth dehydration stress compared to the first stress (Ding et al. 2012). Similarly to A. thaliana (Ding et al. 2012), maize or the desiccation tolerant resurrection plant Craterostigma plantagineum plants pre-exposed to dehydration had a higher relative leaf water content (RWC) than the non-trained plants when exposed to a subsequent dehydration episode (Ding et al. 2014; Liu et al. 2019). Studies on three contrasting potato genotypes (Solanum tuberosum L.) found that a pre-treatment of drought acclimation cycles reduces leaf wilting, induces thicker cuticular layers and more open stomata under a subsequent drought stress, compared to a direct application of drought without pretreatment (Banik et al. 2016).

Generally, ROS are kept at relatively low levels in plants under optimal growth conditions with a balance between ROS scavenging and ROS production (Hossain et al. 2016). Elevated ROS production is caused by stress, and the major source of ROS production are organelles with high oxidative activities (eg. peroxisomes, chloroplasts, and mitochondria) (Sharma et al. 2012). Studies on a drought sensitive cultivar of olive cv. Chétoui showed that pre-exposure to drought induces a better maintenance of ROS homeostasis by increasing contents of polyphenols and activities of ROS scavenging enzymes like guaiacol peroxidase (GP), superoxide dismutase (SOD) and catalase (CAT) decreasing the content of hydrogen peroxide $\left(\mathrm{H}_{2} \mathrm{O}_{2}\right)$ and malondialdehyde (MDA) (Abdallah et al. 2017). Amoah et al. (2019) reported that lipid 
peroxidation, reactive oxygen species, membrane stability, antioxidant enzyme activities, and the contents of $\mathrm{H}_{2} \mathrm{O}_{2}$ and osmolytes increased in wheat plants with drought acclimation under subsequent water stress treatments compared to non-acclimated plants.

The photosynthetic rate is sensitive to abiotic stress, especially dehydration stress. Decrease of photosynthesis under water deficit is initially caused by low levels of $\mathrm{CO}_{2}$ diffusion from the atmosphere to the carboxylation site (Lawlor and Tezara 2009; Wang et al. 2015). Pre-exposure to mild drought could maintain the photosynthetic electron transport in the photosynthetic apparatus of barley plants during a subsequent cold stress (Li et al. 2016). A better photosynthesis rate during severe stress was obtained by exposing winter wheat plants to a mild drought treatment ( $\mathrm{Li}$ et al. 2014). A drought stress memory was also reported for Aptenia cordifolia plants which encountered repeated stresses (Fleta-Soriano et al. 2015). The A. cordifolia plants exposed twice to drought stress had increased chlorophyll a/b ratios compared with a reference group not exposed to a mild stress (Fleta-Soriano et al. 2015).

Abscisic acid (ABA), an essential phytohormone, increases in response to dehydration through a complex equilibrium of synthesis, degradation or conjugation (Kim 2012; Finkelstein 2013). A study of A. cordifolia plants found that ABA levels increased in leaves which encountered two subsequent drought stress episodes compared to plants which were only exposed once (Fleta-Soriano et al. 2015). Neves et al. (2017) observed that citrus plants which underwent multiple exposures to dehydration also had higher ABA levels compared to plants stressed only once. Research on spring wheat (Triticum aestivum L. cv. Vinjett) showed that the wheat plants pre-exposed to a moderate water deficit had higher concentrations of ABA compared to non-primed plants, and the pre-exposure eventually resulted in higher grain yields (Wang et al. 2015).

In plants, a drought stress memory can positively influence biomass or grain yield through efficient regulations of water loss, ROS levels, and photosynthesis. In long-term stress memory experiments, the yield of potatoes was investigated using primed or non-primed tubers (Ramírez et al. 2015). Potato tubers which had been subjected to priming through a mild dehydration treatment had a higher tuber yield than the ones produced in well watered conditions, when the potatoes had been grown in similar conditions (Ramírez et al. 2015). The biomass of Arrhenatherum elatius plants which had been pre-exposed twice to drought stress was higher than that of plants which only encountered a single drought stress (Walter et al. 2011). Wheat plants were used to explore the possible effect of drought stress memory during plant development (Wang et al. 2014). The ascorbate peroxidase activity and photosynthesis rate of wheat plants primed before anthesis were higher whereas the content of malondialdehyde was lower than in the nonprimed wheat plants, and higher grain yield was obtained than in non-primed plants during a severe drought encountered during the grain filling stage (Wang et al. 2014). A moderate drought stress during the vegetative state in spring wheat alleviated yield loss caused by drought during the grain filling stage (Wang et al. 2015).

\section{Molecular mechanisms and epigenetic changes in drought stress memory}

Research on drought stress memory suggests that regulatory mechanisms on the transcriptional level differ in response to a single stress stimulation and repeated stress stimulations (Avramova 2015; Berry and Dean 2015). Changes of gene expression patterns related to stress memory are often correlated with changes of the chromatin status (Campos and Reinberg 2009). The molecular responses of the stress memory act on two levels cis-mechanisms and trans-mechanisms. This means that a memory is generated on chromatin marks (including DNA methylations and histone modifications) and a memory is maintained by feedback loops and cytosol partitioning (Bonasio et al. 2010; Berry and Dean 2015; de Freitas Guedes et al. 2019).

Epigenetic mechanisms like DNA methylations, histone modifications and chromatin structure alterations play an important role in the regulation of gene expression which contribute to epigenetic inheritance in plants (Chinnusamy and Zhu 2009; Friedrich et al. 2019). Changes on the epigenetic level are often inherited or transmitted to the next generation through mitotic cell divisions (Kinoshita and Seki 2014).

\section{DNA methylation}

DNA methylation is a heritable epigenetic mark which is linked to transcriptional repression (Ueda and Seki 2020). DNA methylation is catalyzed by DNA methyltransferases on the fifth carbon of cytosine bases symmetrically (CG and $\mathrm{CHG}, \mathrm{H}=\mathrm{A}, \mathrm{T}$, or $\mathrm{C}$ ) and asymmetrically $(\mathrm{CHH})(\mathrm{Han}$ and Wagner 2014; Vyse et al. 2020). DNA methylation is a reversible process and associates with plant development and environmental responses (Hu et al. 2013). By comparing the DNA methylation patterns of drought sensitive and drought tolerant rice plants changes of DNA methylation were more frequent in drought tolerant rice plants than in drought susceptible rice plants under drought conditions (Wang et al. 2011). To investigate the role of genome-wide DNA methylation patterns in drought stress memory, seedlings of A. thaliana were used in a simulated drought treatment. However, the results showed no correlation between DNA methylation levels and gene expression patterns (Colaneri 
and Jones 2013). When on the other hand differential DNA methylation patterns were analyzed in rice plants using drought susceptible lines, drought tolerant lines, and their F1 hybrids DNA methylation was correlated with drought tolerance, and hypo-methylation of DNA was an indicator of drought tolerance (Joel 2013). DNA methylation patterns identified by DNA analysis provide evidence for droughtinduced DNA methylation associated with acclimation responses in rice (Sapna et al. 2020). Genome-wide bisulphite sequencing of rice plants uncovered that dynamic and distinct patterns of differentially methylated DNA regions are related to drought stress memory. These methylated regions contribute to short-term repeated drought stresses by regulating activity of transposable elements and gene expression (Kou et al. 2021). Studies on wild strawberry (Fragaria vesca) indicated that repeated stress conditions lead to the acquisition of a stable epigenetic memory on the level of DNA methylation (De Kort et al. 2020). Recently, the whole-genome DNA methylation data of the resurrection plant Boea hygrometrica showed that DNA methylation has potential implications on dehydration stress memory (Sun et al. 2021).

\section{Histone modifications}

Histone modifications, including histone methylation, acetylation, ubiquitination, phosphorylation, ADP-ribosylation, and sumoylation, take place in the $\mathrm{N}$-terminal regions of histones through covalent modifications (Zentner and Henikoff 2013; Khan and Zinta 2016). Histone methylation predominantly occurs on lysine and arginine residues including mono-methylation, di-methylation, or tri-methylation (Bannister and Kouzarides 2011; Zentner and Henikoff 2013). The profiles of histone $\mathrm{H} 3$ tri-methylations of lysine 4 and lysine 27 (H3K4me3 and H3K27me3) have been studied for five dehydration stress memory genes in A. thaliana plants (Liu et al. 2014). The results revealed distinct memory responses and showed different activities of transcription during rehydration (Liu et al. 2014). H3K27me3 is a wellknown chromatin repressor for developmentally regulated genes, but it did not block the transcription of dehydration stress-related genes (Liu et al. 2014). The histone modification profiles and the nucleosome occupancy of dehydration responsive genes (including RD20, RD29A and galactinol synthase (GOLS2)) changed during the transition from dehydration to rehydration in A. thaliana (Kim et al. 2012). The presence of RNA polymerase II increased during dehydration and decreased during rehydration, which correlated with transcript profiles (Kim et al. 2012). Correlation of active transcription with the alteration of $\mathrm{H} 3 \mathrm{~K} 4 \mathrm{me} 3$ indicates that this chromatin mark participates in the transcription memory of these genes (Kim et al. 2012). Ding et al. (2012) reported that the relative high levels of phosphorylation of serine 5 (Ser5P) and H3K4me3 of RNA polymerase II persisted while the transcripts of trainable genes fall to a basal level during rehydration, which suggests a correlation with a drought stress memory. Histone acetylation is reversible by transferring the acetyl group to the side chains of lysine and it is able to neutralize the positive charge of the lysine residue (Khan and Zinta 2016; Vyse et al. 2020). The acetylation level of lysine 9 of H3K9ac is related to the active state of dehydration-induced gene expression (Kim et al. 2012). Genome-wide analysis of histone modifications in maize plants showed that drought stress-induced changes of histone modifications could persist after the stress relief. H3K4me3 correlated better with changes of gene expression than H3K27me3 and H3K9ac under drought stress (Forestan et al. 2020). The genome-wide chromatin landscape of five histone markers were determined in the moss Physcomitrella patens to describe its dynamics during development and drought stress (Widiez et al. 2014). Three activating histone marks (H3K4me3, H3K27 Ac and H3K9Ac) exhibit significant changes during development and drought stress. The changes of histone marks and gene expression induced during drought stress are primed to persist during developmental transition (Widiez et al. 2014). Grafting rapeseed (Brassica rapa subsp. oleifera) onto turnip (B. rapa subsp. rapa) indicates that drought stress can be memorized and transmitted from turnip rootstock to rapeseed scion through the modification of histone $\mathrm{H} 3 \mathrm{~K} 4 \mathrm{me} 3$ at the $\Delta 1$-pyrroline5-carboxylate synthetase 1-2 (P5CS1-2) gene (Luo et al. 2020).

\section{RNA molecules and alterations of chromatin structure}

Chromatin changes can be achieved by exchanging canonical histone and specific histone variants, which is referred to as chromatin structure alteration or chromatin remodeling (Vyse et al. 2020). Replacement of histones with variants of different physical properties leads to epigenetic changes. Talbert and Henikoff (2014) proposed that exchange of different histone variants in the chromatin could be a mediating mechanism which takes place when plants encounter environmental changes. The chromatin structure can also be modified by RNA molecules (such as siRNAs, miRNAs, and long non-coding RNAs) through DNA modifications and recruitment of histone methyltransferases (Holoch and Moazed 2015). RNA-directed DNA methylation of cytosine is specific for $\mathrm{CHH}(\mathrm{H}=\mathrm{A}, \mathrm{T}$, or $\mathrm{C}$ ) sequences (Singroha and Sharma 2019). Mozgova et al. (2019) reported that noncoding RNAs are also becoming important players of stress and stress memory responses.

In conclusion, chromatin modifications and gene expression are regulated at various levels during different phases of dehydration and rehydration. Evidence increases for 
epigenetic mechanisms of stress responses and memory in plants, but more studies are needed to understand the role of a drought stress memory in adaption of plants to dehydration.

\section{Cross-stress tolerance}

Under natural field conditions, plants are likely to be exposed to different stresses at the same time or at different stages of their life cycle instead of being exposed to one stress with the same intensity as under experimental laboratory conditions. Thus, cross-stress tolerance is important for growth and development during the complete life cycle of a plant. Cross-stress tolerance may be obtained by establishing acclimation mechanisms, such as morphological changes, accumulation of specific transcription factors and protective metabolites, as well as epigenetic modifications (MunnéBosch and Alegre 2013; Walter et al. 2013). Heat stress, freezing stress and drought stress all of them will cause cellular dehydration and induce acclimation mechanisms, which are partly similar to each other (Beck et al. 2007). Therefore, it is highly possible that activated acclimation mechanisms caused by one type of stress can prevent damage from other stresses which occur later. This phenomenon is termed cross-stress tolerance (Walter et al. 2013).

All processes involved in cross-stress tolerance are regulated by a complex network covering the interaction of multiple external and internal factors, permitting plants to adapt to changing environments (Munné-Bosch and Alegre 2013). The current review highlights the drought stress memoryinduced cross-stress tolerance in plants. Drought priminginduced cross-stress tolerance to cold and heat stress has been observed and reported across various species (Table 1).

\section{Cross-stress tolerance from drought to cold}

Research has shown that a primary exposure to drought could affect a second stress also in form of cold or frost (Table 1). For example, drought stress plays a dominant role by inducing cold tolerance in strawberry (Fragaria $\times$ ananassa) plants (Rajashekar and Panda 2014). The Mediterranean Pinus nigra exposed to an extreme drought stress acquired tolerance to low temperatures occurring in the following years (Kreyling et al. 2012). Li et al. (2015) found that wheat plants pre-exposed to moderate drought stress at the vegetative stage had improved cold tolerance at the stem elongation stage by sustaining ROS homeostasis, reducing leaf water loss, decreasing oxidative injuries of the photosynthetic apparatus, and increased ABA levels. In barley plants, drought priming could also induce cold tolerance, which could be enhanced by application of exogenous melatonin (Li et al. 2016). Studies on three different genotypes of Coffea spp. showed that water deficit during the cold season was beneficial to alleviate the effect of cold stress by increased anti-oxidative defense (Ramalho et al. 2018). These examples confirm that drought-primed plants possess higher RWC and ABA levels, more active antioxidant defense systems, and higher chlorophyll contents and photosynthetic rates than non-primed plants under low temperature stress. The improved protection results in higher grain yield and increased tolerance compared to non-primed plants.

\section{Cross-stress tolerance from drought to heat}

Heat stress limits the growth and productivity of temperate plant species, therefore heat tolerance is needed for growth in areas with high temperature. Drought priming as a suitable method for improving heat tolerance has been reported for various plant species (Table 1). Research with spring wheat (Triticum aestivum L. cv. Vinjett) showed that preexposure to drought stress during stem elongation improved tolerance to high temperature occurring later during grain filling (Wang et al. 2015). The effects of drought priming on grain yield during early developmental stages and nitrogen-use efficiency have been studied in wheat plants under post-anthesis heat stress. Moderate drought stress at the 5th-leaf stage of wheat plants improved carbon assimilation and agronomic nitrogen-use efficiency during later heat stress, resulting in higher grain yield and enhanced stress tolerance (Liu et al. 2017). Zhang et al. (2016) reported that drought priming executed on parent plants could stimulate a cross tolerance in their offspring in winter wheat plants under heat stress conditions. The effect of cross-stress tolerance on lipidomic profiles was analysed in tall fescue (Festuca arundinacea) by Zhang et al. (2019a). The results suggest that drought-primed plants enhanced tolerance to a subsequent heat stress through reprogramming of lipid metabolism and stress signaling (Zhang et al. 2019a). Foliar application of ABA has also a positive role in drought priming-enhanced heat tolerance in tall fescue and A. thaliana, which is associated with the transcriptional up-regulation of genes related to heat protection, ABA responses and stress signaling (Zhang et al. 2019b). The phenomenon of crossstress tolerance was also reported for olive plants (Silva et al. 2018). Olive plants grown under non-irrigated conditions could prevent cumulative damages by heat and UV-B radiation by modulating some tolerance mechanisms compared to well-irrigated plants (Silva et al. 2018). The underlying mechanisms refer to the physiological processes, metabolic pathways, and the regulatory network of genes, contributing to drought priming-improved heat tolerance.

Another type of cross-stress tolerance was reported by Herms and Mattson (1992), they showed that previous exposure to abiotic stress (e.g. drought stress) could induce 
Table 1 Examples of drought stress-cross-tolerance (cold and heat) in plants

\begin{tabular}{|c|c|c|c|c|}
\hline Primary stressor & Species & Cross adaptation & Responsible factors & References \\
\hline Drought & Coffea spp. & Cold & $\begin{array}{l}\text { Higher SOD, APX, GR, CAT } \\
\text { activities; higher expression } \\
\text { level of APXc, APXt }+\mathrm{s} \text {, } \\
\text { PX4; higher amount of non- } \\
\text { enzyme antioxidants (TOC } \\
\text { and ASC) }\end{array}$ & Ramalho et al. (2018) \\
\hline Water stress + cold acclimation & Strawberry & Freezing tolerance & $\begin{array}{l}\text { The expression of COR } 47 \text { and } \\
\text { COR78 orthologs }\end{array}$ & Rajashekar and Panda (2014) \\
\hline Extreme drought & Pinus nigra & Cold hardiness & $\begin{array}{l}\text { Higher soluble carbohydrates } \\
\text { and chain length (ACL) of } \\
\text { fatty acids }\end{array}$ & Kreyling et al. (2012 \\
\hline Drought priming & Wheat & Cold tolerance & $\begin{array}{l}\text { Higher RWC and ABA con- } \\
\text { tent, higher GPX, SOD, APX } \\
\text { and CAT activities; lower } \\
\mathrm{H}_{2} \mathrm{O}_{2} \text { content }\end{array}$ & Li et al. (2015) \\
\hline Drought priming & Barley & Cold tolerance & $\begin{array}{l}\text { Higher ABA and melatonin } \\
\text { concentration; higher SOD, } \\
\text { APX and CAT activities; } \\
\text { higher photosynthetic rate } \\
\text { and chlorophyll content } \\
\text { index; lower } \mathrm{H}_{2} \mathrm{O}_{2} \text { concen- } \\
\text { tration }\end{array}$ & Li et al. (2016) \\
\hline Drought priming & Spring wheat & Heat stress & $\begin{array}{l}\text { Higher ABA concentration; } \\
\text { lower RWC and transpiration } \\
\text { rate; higher } \mathrm{A}_{\mathrm{sat}}^{\mathrm{a}} \text { and } \mathrm{V}_{\max }^{\mathrm{b}}\end{array}$ & Wang et al. (2015) \\
\hline Drought priming & Wheat & Heat stress & $\begin{array}{l}\text { Higher leaf water potential } \\
\text { and chlorophyll content; } \\
\text { higher carbon assimilation } \\
\text { and agronomic nitrogen-use } \\
\text { efficiency; higher grain yield }\end{array}$ & Liu et al. (2017) \\
\hline $\begin{array}{l}\text { Drought priming (parent } \\
\text { plants) }\end{array}$ & Winter wheat & $\begin{array}{l}\text { High temperature stress (off- } \\
\text { spring) }\end{array}$ & $\begin{array}{l}\text { Higher SOD and POD activi- } \\
\text { ties; lower MDA and } \mathrm{H}_{2} \mathrm{O}_{2} \\
\text { content; accumulation of } \\
\text { heat shock proteins and } \\
\text { up-regulation of sucrose } \\
\text { synthesis }\end{array}$ & Zhang et al. (2016) \\
\hline Drought stress & Tall fescue & Heat tolerance & $\begin{array}{l}\text { Higher amount of phospholip- } \\
\text { ids, glycolipids, phosphatidic } \\
\text { acid, phosphatidylcholine, } \\
\text { phosphatidylinositol, } \\
\text { phosphatidylglycerol, and } \\
\text { digalactosyl diacylglycerol; } \\
\text { higher RWC }{ }^{\mathrm{c}} \text {, chlorophyll } \\
\text { content, photochemical } \\
\text { efficiency }\end{array}$ & Zhang et al. (2019a \\
\hline Drought priming & $\begin{array}{l}\text { Tall fescue } \\
\text { and Arabi- } \\
\text { dopsis }\end{array}$ & Heat tolerance & $\begin{array}{l}\text { Up-regulation of } C D P K 3, \\
M P K 3, D R E B 2 A, A R E B 3, \\
M Y B 2, M Y C 4, H S f A 2, \\
H S P 18, \text { and } H S P 70\end{array}$ & Zhang et al. (2019b) \\
\hline Drought treatment & Olive & Heat and UV-B radiation shock & $\begin{array}{l}\text { Lower cell membrane perme- } \\
\text { ability and water loss; } \\
\text { Mitigating effect on quantum } \\
\text { yield of PSII }\end{array}$ & Silva et al. (2018) \\
\hline
\end{tabular}

${ }^{\mathrm{a}} A_{\text {sat }}$ saturated net photosynthesis rate

${ }^{\mathrm{b}} V_{\max }$ the maximum carboxylation rate of Rubisco

${ }^{\mathrm{c}} R W C$ relative water content 
herbivore resistance by increasing carbon-based secondary metabolites. There are many examples that cross memory takes place between drought and cold stress, between drought and heat stress, or even between biotic stress and abiotic stress in different plant species, including $A$. thaliana, strawberry, $P$. nigra, spring wheat, etc. (Shinozaki and Yamaguchi-Shinozaki 2000; Kreyling et al. 2012; Rajashekar and Panda 2014; Li et al. 2015; Wang et al. 2015). Cross-stress tolerance is regulated by a complex network involving the interaction of multiple external and internal factors (Munné-Bosch and Alegre 2013). Due to the irregular and variable growth environments, cross-stress tolerance is extremely important in overcoming unpredictable and diverse stresses and more attention should be paid to it in agricultural practices.

\section{Priming of seeds}

Seed priming has been developed as a low-cost and efficient approach to increase crop yield and to increase tolerance against various stresses (Jisha et al. 2013; Sher et al. 2019). According to the difference of priming agents, seed priming is classified into different types (Sher et al. 2019). Seed priming is not only promoting seed germination and improving plant growth and crop yield, but it also increases tolerance against abiotic stress under changing environmental conditions (Sher et al. 2019; Marthandan et al. 2020). Examples for seed priming which lead to drought tolerance are briefly described in Table 2 . The current review focuses on seed priming correlated to drought tolerance.

Hydropriming of maize (Zea mays L.) significantly improved germination as well as seedling growth under drought stress conditions (Janmohammadi et al. 2008). Hydroprimed cotton seeds (Gossypium hirsutum L.) obtained better germination parameters, growth and higher yield under water shortage conditions (Nasir et al. 2019). In the grass Cleistogenes songorica native to northern China, hydropriming treatments alleviated the detrimental effects of drought stress by decreasing lipid peroxidation and ROS accumulation, and increasing activities of antioxidant enzymes (Tao et al. 2018).

In comparison to seedlings from non-primed chickpea seeds, seedlings obtained from seeds primed with mannitol $(4 \% \mathrm{w} / \mathrm{v})$ had longer roots and shoots under water deficit conditions (Kaur et al. 2002). Primed (treated with different concentrations of PEG) and non-primed seeds of four rice cultivars were germinated under drought stress (imitated with PEG) to examine the effects of seed priming and physiological characteristics of rice plants (Sun et al. 2010). The study showed that a suitable concentration of PEG improved germination indices, as well as quality and drought tolerance of seedlings under drought stress. The physiological changes were correlated with an increase in proline, soluble proteins, phenylalanine ammonia lyase (PAL), peroxidase (POD), SOD and CAT, and decreased soluble sugars and MDA (Sun et al. 2010). The effect of seed osmopriming (with $\mathrm{CaCl}_{2}$ solution) on wheat yield was evaluated in a field experiment (Hussain et al. 2018). The osmoprimed seeds led to increased yield and crop allometry and improved productivity under drought stress, due to establishment of early and uniform tolerance mechanisms (Hussain et al. 2018). Melatonin-primed rapeseeds had better germination parameters and subsequent better seedling growth under drought stress. This phenomenon is ascribed to the effects of melatonin-priming, including improvement of stomatal traits, strengthening of cell walls, enhanced activities of enzymatic and non-enzymatic antioxidants, and accumulation of osmoprotectants (Khan et al. 2019).

Seed priming using $50 \mathrm{ppm}$ of auxin increased seed germination and the number of seminal roots whereas $100 \mathrm{ppm}$ of gibberellin, $50 \mathrm{ppm}$ of cytokinin, and $50 \mathrm{ppm}$ of ABA improved seed performance under drought stress conditions, respectively (Eisvand et al. 2010). Research on wheat plants showed that hormonal priming with gibberellic acid or auxin significantly enhanced the growth and development of wheat plants, resulting in higher grain yield compared with nonprimed plants (Ulfat et al. 2017; Bagheri et al. 2019).

These and related observations could contribute to the development of drought tolerant crop plants. In general, the overall growth of plants is enhanced under drought stress treatments. This could be further explored in future studies of plant priming or plant stress memory.

\section{Priming of resurrection plants}

Not only seeds but also desiccation tolerant resurrection plants are responsive to priming and subsequently a stress memory is build-up. Stress memory was observed in the resurrection plant Craterostigma plantagineum which belongs to the Linderniaceae family. After being exposed to four dehydration/rehydration treatment cycles, expression of four representative stress-related genes and ROS pathway-related genes gradually increased, accompanied by increasing levels of SOD activity, proline content and sucrose content, conversely the $\mathrm{H}_{2} \mathrm{O}_{2}$ content and electrolyte leakage (EL) decreased, which indicates a gain of stress tolerance and also points to a stress memory (Liu et al. 2019; Liu 2020). Similarly, the resurrection plant $B$. hygrometrica acquired desiccation tolerance after priming through a pretreatment of slow dehydration (Zhu et al. 2015). Mitra et al. (2013) proposed that histone modifications in $B$. hygrometrica are altered during drought acclimation and are retained, which causes activation of downstream genes during subsequent desiccation. Metabolomes were compared between the 
Table 2 Examples of seed priming-induced drought tolerance in plants

\begin{tabular}{|c|c|c|c|c|}
\hline Types & Chemicals & Species & Responsible factors & References \\
\hline Hydropriming & Water & Maize & $\begin{array}{l}\text { Significantly improved ger- } \\
\text { mination index, seedling } \\
\text { vigour index and length of } \\
\text { seedling }\end{array}$ & Janmohammadi et al. (2008) \\
\hline $\begin{array}{l}\text { Hydropriming and } \\
\text { osmopriming }\end{array}$ & Water and mannitol (4\%) & Chickpea & $\begin{array}{l}\text { Higher activities of amylase, } \\
\text { invertases (acid and } \\
\text { alkaline), sucrose synthase } \\
\text { and sucrose phosphate } \\
\text { synthase; longer root and } \\
\text { shoot length }\end{array}$ & Kaur et al. (2002) \\
\hline $\begin{array}{l}\text { Hydropriming and } \\
\text { osmopriming }\end{array}$ & Water and $\mathrm{PEG}^{\mathrm{a}}$ & Rice & $\begin{array}{l}\text { Higher proline and soluble } \\
\text { protein content, PAL } \\
\text { SOD, CAT, and POD } \\
\text { activities; lower soluble } \\
\text { sugar and MDA con- } \\
\text { tent; accelerated glucose } \\
\text { metabolism }\end{array}$ & Sun et al. (2010) \\
\hline $\begin{array}{l}\text { Hydropriming and } \\
\text { osmopriming }\end{array}$ & Water and PEG-6000 & Cleistogenes songorica & $\begin{array}{l}\text { Lower lipid peroxidation } \\
\text { and } \mathrm{H}_{2} \mathrm{O}_{2} \text { content; greater } \\
\text { antioxidant enzyme activ- } \\
\text { ity; higher nuclear DNA } \\
\text { contents during cell cycle }\end{array}$ & Tao et al. (2018) \\
\hline $\begin{array}{l}\text { Hydropriming and } \\
\text { osmopriming }\end{array}$ & Water and $\mathrm{CaCl}_{2}$ & Cotton & $\begin{array}{l}\text { Higher emergence index, } \\
\text { mean germination time, } \\
\text { number of bolls per plant, } \\
\text { boll weight per plant, lint } \\
\text { weight, seed weight, plant } \\
\text { height }\end{array}$ & Nasir et al. (2019) \\
\hline Osmopriming & $\mathrm{CaCl}_{2}(-1.25 \mathrm{MPa})$ & Wheat & $\begin{array}{l}\text { Improved leaf area index, } \\
\text { leaf area duration, and } \\
\text { crop growth rate }\end{array}$ & Hussain et al. ((2018) \\
\hline Osmopriming & Melatonin & Rapeseed & $\begin{array}{l}\text { Improved stomatal number, } \\
\text { length, width, and cell } \\
\text { wall strength; higher anti- } \\
\text { oxidant system activities }\end{array}$ & Khan et al. (2019) \\
\hline Biopriming & Mycorrhiza fungi & Sesame & $\begin{array}{l}\text { Higher amount of chlo- } \\
\text { rophyll index, nitrogen, } \\
\text { phosphorus, potassium, } \\
\text { zinc, iron and copper } \\
\text { uptake; Lower water } \\
\text { consumption }\end{array}$ & Askari et al. (2018) \\
\hline Biopriming & Pseudomonas fluorescens & Okra & $\begin{array}{l}\text { Higher RWC, sugar, and } \\
\text { free amino acids content; } \\
\text { higher activity of pheno- } \\
\text { lics, ascorbate glutathione, } \\
\text { SOD, CAT, APX and } \\
\text { GPX; alleviated mem- } \\
\text { brane damage and protein } \\
\text { denaturation }\end{array}$ & Pravisya et al. (2019) \\
\hline Solid matrix priming & $\begin{array}{l}\text { Multi-walled carbon nano- } \\
\text { tubes }\end{array}$ & Caucasian alder & $\begin{array}{l}\text { Higher seed vigour index, } \\
\text { root and stem lengths, and } \\
\text { dry weights }\end{array}$ & Rahimi et al. (2016) \\
\hline Solid matrix priming & $\begin{array}{l}\text { Multi-walled carbon nano- } \\
\text { tubes }\end{array}$ & Hopbush & $\begin{array}{l}\text { Improved seed germination } \\
\text { percentage, mean germi- } \\
\text { nation time, root and stem } \\
\text { lengths, fresh and dry } \\
\text { weights of root and stem }\end{array}$ & Yousefi et al. (2017) \\
\hline
\end{tabular}


Table 2 (continued)

\begin{tabular}{|c|c|c|c|c|}
\hline Types & Chemicals & Species & Responsible factors & References \\
\hline Nutripriming & $\mathrm{Zinc}\left(\mathrm{ZnSO}_{4}\right)$ & Durum wheat & $\begin{array}{l}\text { Higher seedling height and } \\
\text { SOD activity; better seed } \\
\text { germination }\end{array}$ & Candan et al. (2018) \\
\hline Nutripriming & $\mathrm{Mg}\left(\mathrm{NO}_{3}\right)_{2}$ and $\mathrm{ZnSO}_{4}$ & Wheat & $\begin{array}{l}\text { Higher yield and yield } \\
\text { attributes parameters } \\
\text { (spike length, spike num- } \\
\text { ber, spike weight, seed } \\
\text { number) }\end{array}$ & Singhal et al. (2019) \\
\hline Nutripriming & $\mathrm{Zinc}\left(\mathrm{ZnSO}_{4}\right)$ & Wheat & $\begin{array}{l}\text { Higher dissipation of excess } \\
\text { energy; higher leaf suc- } \\
\text { culence values }\end{array}$ & Pavia et al. (2019) \\
\hline Hormonal priming & $\begin{array}{l}\text { Auxin, cytokinin, gibberel- } \\
\text { lin, cytokinin, ABA }\end{array}$ & Tall wheatgrass & $\begin{array}{l}\text { Higher CAT, GR, POD, } \\
\text { SOD activities; higher } \\
\text { germination percentage } \\
\text { and rate of germination }\end{array}$ & Eisvand et al. (2010) \\
\hline Hormonal priming & Gibberellic acid & Wheat & $\begin{array}{l}\text { Better growth and develop- } \\
\text { ment; higher yield }\end{array}$ & Ulfat et al. (2017) \\
\hline Hormonal priming & Auxin & Wheat & Higher grain yield & Bagheri et al. (2019) \\
\hline
\end{tabular}

${ }^{\text {a }} P E G$ polyethylene glycol

${ }^{\mathrm{b}} P A L$ phenylalanine ammonia lyase

acclimated and non-acclimated desiccation tolerant plant Myrothamnus flabellifolia Welw. (Bentley and Farrant 2020), and it was shown that long-term acclimation results in large-scale reprogramming of the metabolome (Bentley and Farrant 2020).

Cross-stress tolerance between desiccation and freezing temperatures was found in resurrection plants like Haberlea rhodopensis Friv. and Ramonda myconi. Georgieva et al. (2021) reported that $H$. rhodopensis Friv. has unique properties and can withstand desiccation as well as freezing temperatures. The adaptation of $H$. rhodopensis to low temperature is based on the readjustment of the photosynthetic apparatus, which has undergone modifications during primary desiccation (Mihailova et al. 2020). The resurrection plant $R$. myconi has been used to investigate the physiological mechanisms underpinning cross-stress tolerance between desiccation and freezing (Fernández-Marín et al. 2020). The results showed that protection of chloroplast structures are a response common for desiccation and low temperature in $R$. myconi (Fernández-Marín et al. 2020).

Common responses are observed during seed priming and priming of resurrection plants. The re-synthesis of degraded proteins upon rehydration based on stable storage of transcripts in the desiccated state, the increase of tocopherol in membranes upon desiccation, and the expression of targeted genes and proteins during dehydration are common dehydration responses in seeds and vegetative tissues (Oliver et al. 2020). Despite these observations, it is not possible at present to firmly conclude that the priming mechanisms are identical in seeds and resurrection plants.
It stimulated us to address the question whether the desiccation tolerant resurrection plant $C$. plantagineum could gain tolerance to biotic and/or abiotic stress, through similar treatments as seed priming. Desiccated $C$. plantagineum plants can be treated with hydropriming, osmopriming, solid matrix priming, biopriming, nutripriming, hormonal priming, and thermopriming methods which have already been used for seed priming. If untreated $C$. plantagineum plants are treated in different ways, then stress memory responses are induced during a second treatment which is an example for cross-stress tolerance. However, if the experiments are done with already desiccated $C$. plantagineum plants, it may induce different responses compared to untreated plants. This means that the physiological condition of the plant which undergoes priming treatments is important for the response. This hypothesis might contribute to uncover a new sight of plant priming or plant stress memory.

\section{Concluding remarks and future perspectives}

Climate change and unevenly distributed precipitations seriously affect global agricultural production and food security. How to minimize adverse effects of climate change and to meet the food demand of the increasing human population becomes an urgent problem. Considering the conventional techniques (e.g. selection and hybridization) and recently genetic engineering (e.g. transgenic technology, gene mutation and polyploidy breeding) have limitations, such as the length of time, large man power, or the restrictions based 


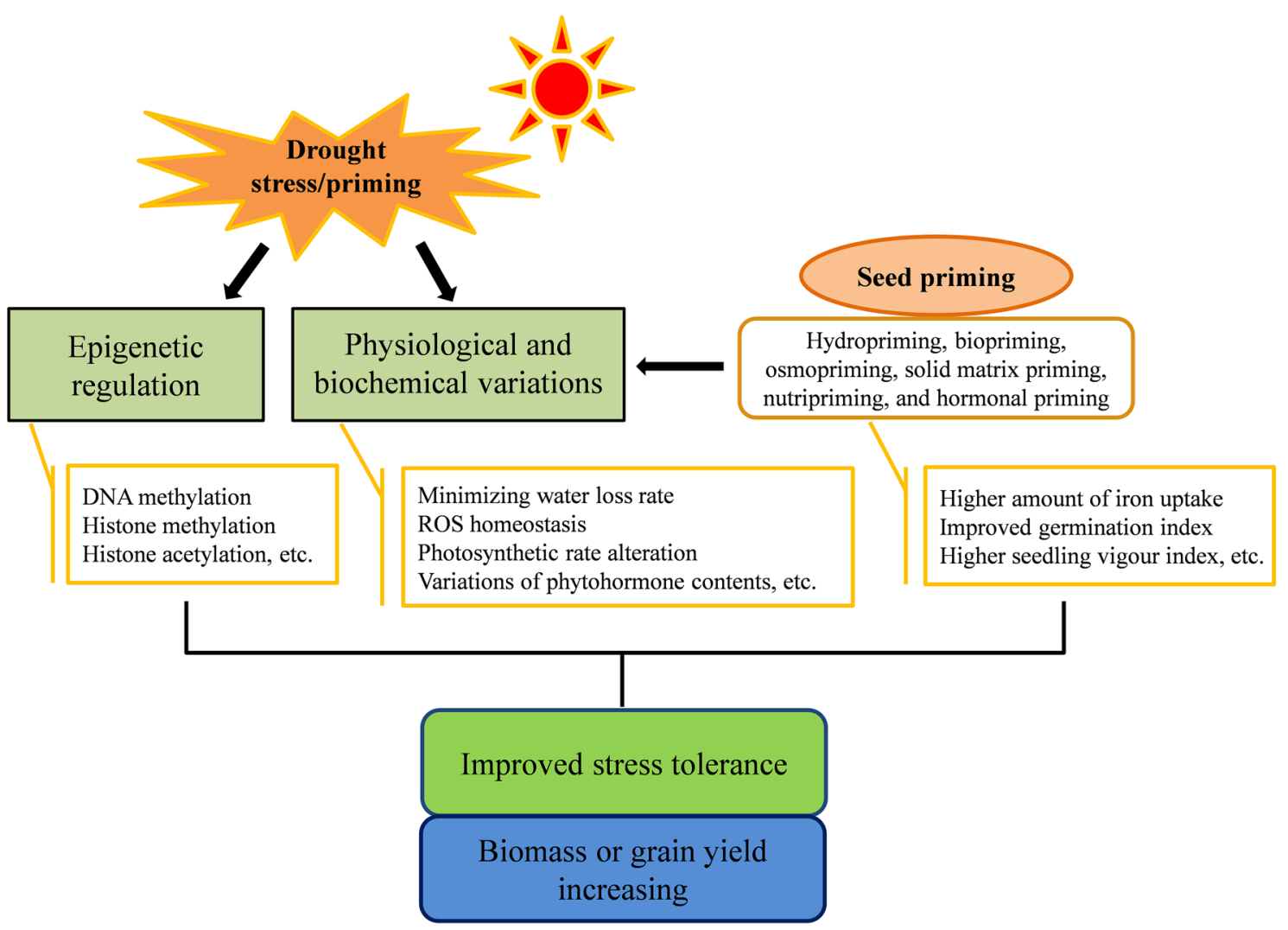

Fig. 1 Overview of drought stress responses and seed priming in the context of drought tolerance in plants

on biosafety issues and environmental protection problems. Hence, alternative technologies emerged as promising solutions. As we describe in this review, methods involved in plant stress memory, cross-stress tolerance, and seed priming have become effective and favorable techniques for environmentally friendly and sustainable agriculture (Fig. 1). Currently, there is increasing evidence in the literature how to alleviate the negative effects of dehydration stress based on the plant immune system. However, biochemical and molecular mechanisms of plant memory and seed priming still need to be investigated for precise and reliable applications of this approach. Future research needs to focus on the elucidation of how long the stress memory can persist, how to prolong and increase the positive effects of plant memory, and how to apply priming on a large scale to diverse plants.

\section{Author contribution statement}

DB and XL conceived the manuscript. XL and WQ wrote the manuscript. DB, XL and WQ revised the article.

Acknowledgements Xun Liu acknowledges the support from the China Scholarship Council.
Funding Open Access funding enabled and organized by Projekt DEAL.

Open Access This article is licensed under a Creative Commons Attribution 4.0 International License, which permits use, sharing, adaptation, distribution and reproduction in any medium or format, as long as you give appropriate credit to the original author(s) and the source, provide a link to the Creative Commons licence, and indicate if changes were made. The images or other third party material in this article are included in the article's Creative Commons licence, unless indicated otherwise in a credit line to the material. If material is not included in the article's Creative Commons licence and your intended use is not permitted by statutory regulation or exceeds the permitted use, you will need to obtain permission directly from the copyright holder. To view a copy of this licence, visit http://creativecommons.org/licenses/by/4.0/.

\section{References}

Abdallah MB, Methenni K, Nouairi I, Zarrouk M, Youssef NB (2017) Drought priming improves subsequent more severe drought in a drought-sensitive cultivar of olive cv Chétoui. Sci HorticAmsterdam 221:43-52. https://doi.org/10.1016/j.scienta.2017. 04.021

Abdelraheem A, Esmaeili N, O’Connell M, Zhang J (2019) Progress and perspective on drought and salt stress tolerance in cotton. Ind Crops Prod 130:118-129. https://doi.org/10.1016/j.indcrop. 2018.12.070 
Amoah JN, Ko CS, Yoon JS, Weon SY (2019) Effect of drought acclimation on oxidative stress and transcript expression in wheat (Triticum aestivum L.). J Plant Interact 14:492-505. https://doi. org/10.1080/17429145.2019.1662098

Askari A, Ardakani MR, Vazan S, Paknejad F, Hosseini Y (2018) The effect of mycorrhizal symbiosis and seed priming on the amount of chlorophyll index and absorption of nutrients under drought stress in sesame plant under field conditions. Appl Ecol Env Res $16: 335-357$

Avramova Z (2015) Transcriptional 'memory' of a stress: transient chromatin and memory (epigenetic) marks at stress-response genes. Plant J 83:149-159. https://doi.org/10.1111/tpj.12832

Bagheri N, Alizadeh O, Zadeh SS, Aref F, Ordookhani K (2019) Evaluation of auxin priming and plant growth promoting Rhizobacteria on yield and yield components of wheat under drought stress. Eurasia J Biosci 13:711-716

Banik P, Zeng W, Tai H, Bizimungu B, Tanino K (2016) Effects of drought acclimation on drought stress resistance in potato (Solanum tuberosum L.) genotypes. Environ Exp Bot 126:76-89. https://doi.org/10.1016/j.envexpbot.2016.01.008

Bannister AJ, Kouzarides T (2011) Regulation of chromatin by histone modifications. Cell Res 21:381-395. https://doi.org/10.1038/cr. 2011.22

Beck EH, Fettig S, Knake C, Hartig K, Bhattarai T (2007) Specific and unspecific responses of plants to cold and drought stress. $\mathrm{J}$ Biosci 32:501-510. https://doi.org/10.1007/s12038-007-0049-5

Bentley J, Farrant JM (2020) Field and acclimated metabolomes of a resurrection plant suggest strong environmental regulation in the extreme end of the species' range. S Afr J Bot 135:127-136. https://doi.org/10.1016/j.sajb.2020.09.003

Berry S, Dean C (2015) Environmental perception and epigenetic memory: mechanistic insight through FLC. Plant J 83:133-148. https://doi.org/10.1111/tpj.12869

Bonasio R, Tu S, Reinberg D (2010) Molecular signals of epigenetic states. Science 330:612-616

Bruce TJA, Matthes MC, Napier JA, Pickett JA (2007) Stressful "memories" of plants: evidence and possible mechanisms. Plant Sci 173:603-608. https://doi.org/10.1016/j.plantsci.2007.09.002

Campos EI, Reinberg D (2009) Histones: annotating chromatin. Annu Rev Genet 43:559-599. https://doi.org/10.1146/annurev.genet. 032608.103928

Candan N, Cakmak I, Ozturk L (2018) Zinc-biofortified seeds improved seedling growth under zinc deficiency and drought stress in durum wheat. J Plant Nutr Soil Sci 181:388-395. https:// doi.org/10.1002/jpln.201800014

Chawla N (2019) Defensive role of nitric oxide (NO) under drought stress in plants: mini. J ETIR 6:898-901

Chen K, Fessehaie A, Arora R (2012) Selection of reference genes for normalizing gene expression during seed priming and germination using qPCR in Zea mays and Spinacia oleracea. Plant Mol Biol Rep 30:478-487. https://doi.org/10.1007/ s11105-011-0354-X

Cheng J, Wang L, Zeng P, He Y, Zhou R, Zhang H, Wang Z (2017) Identification of genes involved in rice seed priming in the early imbibition stage. Plant Biol 19:61-69. https://doi.org/10.1111/ plb. 12438

Chinnusamy V, Zhu JK (2009) Epigenetic regulation of stress responses in plants. Curr Opin Plant Biol 12:133-139. https://doi.org/10. 1016/j.pbi.2008.12.006

Colaneri AC, Jones AM (2013) Genome-wide quantitative identification of DNA differentially methylated sites in Arabidopsis seedlings growing at different water potential. PLoS ONE 8:e59878. https://doi.org/10.1371/journal.pone.0059878

de Freitas Guedes FA, Menezes-Silva PE, DaMatta FM, AlvesFerreira M (2019) Using transcriptomics to assess plant stress memory. Theor Exp Plant Phys 31:47-58. https://doi.org/10. 1007/s40626-018-0135-0

De Kort H, Panis B, Deforce D, Van Nieuwerburgh F, Honnay O (2020) Ecological divergence of wild strawberry DNA methylation patterns at distinct spatial scales. Mol Ecol 29:4871-4881. https:// doi.org/10.1111/mec.15689

Ding Y, Fromm M, Avramova Z (2012) Multiple exposures to drought 'train' transcriptional responses in Arabidopsis. Nat Commun 3:740. https://doi.org/10.1038/ncomms 1732

Ding Y, Virlouvet L, Liu N, Riethoven J, Fromm M, Avramova Z (2014) Dehydration stress memory genes of Zea mays; comparison with Arabidopsis thaliana. BMC Plant Biol 14:141. https:// doi.org/10.1186/1471-2229-14-141

Eisvand HR, Tavakkol-Afshari R, Sharifzadeh F, Maddah Arefi H, Hesamzadeh Hejazi SM (2010) Effects of hormonal priming and drought stress on activity and isozyme profiles of antioxidant enzymes in deteriorated seed of tall wheatgrass (Agropyron elongatum Host). Seed Sci Technol 38:280-297. https://doi.org/10. 15258/sst.2010.38.2.02

Faralli M, Lektemur C, Rosellini D, Gürel F (2015) Effects of heat shock and salinity on barley growth and stress-related gene transcription. Biol Plant 59:537-546. https://doi.org/10.1007/ s10535-015-0518-x

Farooq M, Basra SMA, Wahid A, Rehman H (2009) Exogenously applied nitric oxide enhances the drought tolerance in fine grain aromatic rice (Oryza sativa L.). J Agron Crop Sci 195:254-261. https://doi.org/10.1111/j.1439-037X.2009. 00367.x

Fernández-Marín B, Nadal M, Gago J, Fernie AR, López-Pozo M, Artetxe U, García-Plazaola JI, Verhoeven A (2020) Born to revive: molecular and physiological mechanisms of double tolerance in a paleotropical and resurrection plant. New Phytol 226:741-759. https://doi.org/10.1111/nph.16464

Ferreira-Silva SL, Voigt EL, Silva EN, Maia JM, Fontenele AV, Silveira JAG (2011) High temperature positively modulates oxidative protection in salt-stressed cashew plants. Environ Exp Bot 74:162-170. https://doi.org/10.1016/j.envexpbot.2011.05.015

Finkelstein R (2013) Abscisic acid synthesis and response. Arabidopsis Book 11:e0166

Fleta-Soriano E, Munné-Bosch S (2016) Stress memory and the inevitable effects of drought: a physiological perspective. Front Plant Sci 7:143. https://doi.org/10.3389/fpls.2016.00143

Fleta-Soriano E, Pinto-Marijuan M, Munné-Bosch S (2015) Evidence of drought stress memory in the facultative CAM, Aptenia cordifolia: possible role of phytohormones. PLoS ONE 10:e0135391. https://doi.org/10.1371/journal.pone.0135391

Forestan C, Farinati S, Zambelli F, Pavesi G, Rossi V, Varotto S (2020) Epigenetic signatures of stress adaptation and flowering regulation in response to extended drought and recovery in Zea mays. Plant Cell Environ 43:55-75. https://doi.org/10.1111/pce.13660

Friedrich T, Faivre L, Bäurle I, Schubert D (2019) Chromatin-based mechanisms of temperature memory in plants. Plant Cell Environ 42:762-770. https://doi.org/10.1111/pce.13373

Georgieva K, Mihailova G, Gigova L, Dagnon S, Simova-Stoilova L, Velitchkova M (2021) The role of antioxidant defense in freezing tolerance of resurrection plant Haberlea rhodopensis. Physiol Mol Biol Pla 27:1119-1133. https://doi.org/10.1007/ s12298-021-00998-0

Han SK, Wagner D (2014) Role of chromatin in water stress responses in plants. J Exp Bot 65:2785-2799. https://doi.org/10.1093/jxb/ ert403

He D, Yang P (2013) Proteomics of rice seed germination. Front Plant Sci 4:246. https://doi.org/10.3389/fpls.2013.00246

Herms DA, Mattson WJ (1992) The dilemma of plants: to grow or defend. Q Rev Biol 67:283-335 
Hilker M, Schwachtje J, Baier M et al (2016) Priming and memory of stress responses in organisms lacking a nervous system. Biol Rev 91:1118-1133. https://doi.org/10.1111/brv.12215

Holoch D, Moazed D (2015) RNA-mediated epigenetic regulation of gene expression. Nat Rev Genet 16:71-84. https://doi.org/10. 1038/nrg3863

Hossain MA, Burritt DJ, Fujita M (2016) Cross-stress tolerance in plants: molecular mechanisms and possible involvement of reactive oxygen species and methylglyoxal detoxification systems. In: Tuteja N, Gill SS (eds) Abiotic stress response in plants. Wiley, New York, pp 323-375

Hossain MA, Li ZG, Hoque TS, Burritt DJ, Fujita M, Munné-Bosch S (2018) Heat or cold priming-induced cross-tolerance to abiotic stresses in plants: key regulators and possible mechanisms. Protoplasma 255:399-412. https://doi.org/10.1007/ s00709-017-1150-8

Hu Y, Zhu N, Wang X, Yi Q, Zhu D, Lai Y, Zhao Y (2013) Analysis of rice Snf2 family proteins and their potential roles in epigenetic regulation. Plant Physiol Bioch 70:33-42. https://doi.org/ 10.1016/j.plaphy.2013.05.001

Hussain M, Farooq M, Sattar A, Ijaz M, Sher A, Ul-Allah S (2018) Mitigating the adverse effects of drought stress through seed priming and seed quality on wheat (Triticum aestivum L.) productivity. Pak J Agr Sci 55:313-319

Janmohammadi M, Dezfuli PM, Sharifzadeh F (2008) Seed invigoration techniques to improve germination and early growth of inbred line of maize under salinity and drought stress. Gen Appl Plant Physiol 34:215-226

Jisha KC, Vijayakumari K, Puthur JT (2013) Seed priming for abiotic stress tolerance: an overview. Acta Physiol Plant 35:1381-1396. https://doi.org/10.1007/s11738-012-1186-5

Joel AJ (2013) Epigenetic responses to drought stress in rice (Oryza sativa $\mathrm{L}$.). Physiol Mol Biol Plants 19:379-387. https://doi.org/ 10.1007/s12298-013-0176-4

Kaur S, Gupta A, Kaur N (2002) Effect of osmo- and hydropriming of chickpea seeds on seedling growth and carbohydrate metabolism under water deficit stress. Plant Growth Regul 37:17-22. https:// doi.org/10.1023/A:1020310008830

Khan A, Zinta G (2016) Drought stress and chromatin: an epigenetic perspective. In: Hossain MA, Wani SH, Bhattacharjee S, Burritt DJ, Tran LP (eds) Drought Stress Tolerance in Plants, vol 2. Springer, Cham, pp 571-586. https://doi.org/10.1007/978-3319-32423-4_21

Khan MN, Zhang J, Luo T, Liu J, Rizwan M, Fahad S, Xu Z, Hu L (2019) Seed priming with melatonin coping drought stress in rapeseed by regulating reactive oxygen species detoxification: antioxidant defense system, osmotic adjustment, stomatal traits and chloroplast ultrastructure perseveration. Ind Crop Prod 140:111597. https://doi.org/10.1016/j.indcrop.2019.111597

Kim TH (2012) Plant stress surveillance monitored by ABA and disease signaling interactions. Mol Cells 33:1-7. https://doi.org/10. 1007/s10059-012-2299-9

Kim JM, To TK, Ishida J, Matsui A, Kimura H, Seki M (2012) Transition of chromatin status during the process of recovery from drought stress in Arabidopsis thaliana. Plant Cell Physiol 53:847-856. https://doi.org/10.1093/pcp/pcs053

Kinoshita T, Seki M (2014) Epigenetic memory for stress response and adaptation in plants. Plant Cell Physiol 55:1859-1863. https:// doi.org/10.1093/pcp/pcu125

Kou S, Gu Q, Duan L, Liu G, Yuan P, Li H, Wu Z, Liu W, Huang P, Liu L (2021) Genome-wide bisulphite sequencing uncovered the contribution of DNA methylation to rice short-term drought memory formation. J Plant Growth Regul 2021:1-15. https://doi. org/10.1007/s00344-021-10483-3

Kreyling J, Wiesenberg GLB, Thiel D, Wohlfart C, Huber G, Walter J, Jentsch A, Konnert M, Beierkuhnlein C (2012) Cold hardiness of Pinus nigra Arnold as influenced by geographic origin, warming, and extreme summer drought. Environ Exp Bot 78:99-108. https://doi.org/10.1016/j.envexpbot.2011.12.026

Lawlor DW, Tezara W (2009) Causes of decreased photosynthetic rate and metabolic capacity in water-deficient leaf cells: a critical evaluation of mechanisms and integration of processes. Ann Bot 103:561-579. https://doi.org/10.1093/aob/men244

Li ZG, Gong M (2011) Mechanical stimulation-induced cross-adaptation in plants: an overview. J Plant Biol 54:358-364. https://doi. org/10.1007/s12374-011-9178-3

Li X, Liu F (2016) Drought stress memory and drought stress tolerance in plants: biochemical and molecular basis. In: Hossain MA (ed) Drought stress tolerance in plants 1. Springer, Cham, pp 17-44. https://doi.org/10.1007/978-3-319-28899-4_2

Li X, Cai J, Liu F, Dai T, Cao W, Jiang D (2014) Physiological, proteomic and transcriptional responses of wheat to combination of drought or waterlogging with late spring low temperature. Funct Plant Biol 41:690-703. https://doi.org/10.1071/FP13306

Li X, Topbjerg HB, Jiang D, Liu F (2015) Drought priming at vegetative stage improves the antioxidant capacity and photosynthesis performance of wheat exposed to a short-term low temperature stress at jointing stage. Plant Soil 393:307-318. https://doi.org/10.1007/s11104-015-2499-0

Li X, Tan DX, Jiang D, Liu F (2016) Melatonin enhances cold tolerance in drought-primed wild-type and abscisic acid-deficient mutant barley. J Pineal Res 61:328-339. https://doi.org/10. $1111 /$ jpi. 12350

Liu X (2020) The mechanisms of stress memory responses and translational regulation during dehydration and rehydration in the resurrection plant Craterostigma plantagineum. Dissertation, University of Bonn

Liu N, Ding Y, Fromm M, Avramova Z (2014) Different gene-specific mechanisms determine the 'revised-response' memory transcription patterns of a subset of A. thaliana dehydration stress responding genes. Nucleic Acids Res 42:5556-5566. https://doi.org/10.1093/nar/gku220

Liu S, Li X, Larsen DH, Zhu X, Song F, Liu F (2017) Drought priming at vegetative growth stage enhances nitrogen-use efficiency under post-anthesis drought and heat stress in wheat. J Agron Crop Sci 203:29-40. https://doi.org/10.1111/jac.12190

Liu X, Challabathula D, Quan W, Bartels D (2019) Transcriptional and metabolic changes in the desiccation tolerant plant Craterostigma plantagineum during recurrent exposures to dehydration. Planta 249:1017-1035. https://doi.org/10.1007/ s00425-018-3058-8

Luo L, Zheng Y, Gao Z, Chen Q, Kong X, Yang Y (2020) Grafting improves drought stress memory by increasing the P5CS1 gene expression in Brassica rapa. Plant Soil 452:61-72. https://doi. org/10.1007/s11104-020-04547-8

Mahmood T, Khalid S, Abdullah M, Ahmed Z, Shah MKN, Ghafoor A, Du X (2020) Insights into drought stress signaling in plants and the molecular genetic basis of cotton drought tolerance. Cells 9:105. https://doi.org/10.3390/cells9010105

Marthandan V, Geetha R, Kumutha K, Renganathan VG, Karthikeyan A, Ramalingam J (2020) Seed priming: a feasible strategy to enhance drought tolerance in crop plants. Int J Mol Sci 21:8258. https://doi.org/10.3390/ijms21218258

Mihailova G, Solti Á, Sárvári É, Keresztes Á, Rapparini F, Velitchkova M, Simova-Stoilova L, Aleksandrov V, Georgieva K (2020) Freezing tolerance of photosynthetic apparatus in the homoiochlorophyllous resurrection plant Haberlea rhodopensis. Environ Exp Bot 178:104157. https://doi.org/10.1016/j.envexpbot. 2020.104157

Mitra J, Xu G, Wang B, Li M, Deng X (2013) Understanding desiccation tolerance using the resurrection plant Boea hygrometrica as 
a model system. Front Plant Sci 4:446. https://doi.org/10.3389/ fpls.2013.00446

Mozgova I, Mikulski P, Pecinka A, Farrona S (2019) Epigenetic mechanisms of abiotic stress response and memory in plants. In: Alvarez-Venegas R, De-la-Peña C, Casas-Mollano JA (eds) Epigenetics in plants of agronomic importance: fundamentals and applications. Springer, Cham, pp 1-64. https://doi.org/10. 1007/978-3-030-14760-0_1

Munné-Bosch S, Alegre L (2013) Cross-stress tolerance and stress "memory" in plants. Environ Exp Bot 94:1-88

Nasir MW, Yasmeen A, Imran M, Zoltan T (2019) Seed priming to alleviate drought stress in cotton. J Environ Agr Sci 21:14-22

Neves DM, da Hora Almeida LA, Santana-Vieira DDS, Freschi L, Ferreira CF, dos Santos Soares Filho W, Costa MGC, Micheli F, Filho MAC, da Silva GA (2017) Recurrent water deficit causes epigenetic and hormonal changes in citrus plants. Sci Rep 7:13684. https://doi.org/10.1038/s41598-017-14161-x

Oliver MJ, Farrant JM, Hilhorst HWM, Mundree S, Williams B, Bewley JD (2020) Desiccation tolerance: avoiding cellular damage during drying and rehydration. Annu Rev Plant Biol 71:435-460. https://doi.org/10.1146/annurev-arplant-071219-105542

Pavia I, Roque J, Rocha L, Ferreira H, Castro C, Carvalho A, Silva E, Brito C, Gonçalves A, Lima-Brito J, Correia C (2019) Zinc priming and foliar application enhances photoprotection mechanisms in drought-stressed wheat plants during anthesis. Plant Physiol Bioch 140:27-42. https://doi.org/10.1016/j. plaphy.2019.04.028

Pravisya P, Jayaram KM, Yusuf A (2019) Biotic priming with Pseudomonas fluorescens induce drought stress tolerance in Abelmoschus esculentus (L.) Moench (Okra). Physiol Mol Biol Pla 25:101-112. https://doi.org/10.1007/s12298-018-0621-5

Rahimi D, Kartoolinejad D, Nourmohammadi K, Naghdi R (2016) Increasing drought resistance of Alnus subcordata C.A. Mey. seeds using a nano priming technique with multi-walled carbon nanotubes. J for Sci 62:269-278

Rajashekar CB, Panda M (2014) Water stress is a component of cold acclimation process essential for inducing full freezing tolerance in strawberry. Sci Hortic-Amsterdam 174:54-59. https://doi.org/ 10.1016/j.scienta.2014.05.007

Ramalho JC, Rodrigues AP, Lidon FC, Marques LMC, Leitão AE, Fortunato AS, Pais IP, Silva MJ, Scotti-Campos P, Lopes A, Reboredo FH, Ribeiro-Barros AI (2018) Stress cross-response of the antioxidative system promoted by superimposed drought and cold conditions in Coffea spp. PLoS One 13:e198694. https:// doi.org/10.1371/journal.pone.0198694

Ramírez DA, Rolando JL, Yactayo W, Monneveux P, Mares V, Quiroz $\mathrm{R}$ (2015) Improving potato drought tolerance through the induction of long-term water stress memory. Plant Sci 238:26-32. https://doi.org/10.1016/j.plantsci.2015.05.016

Sapna H, Ashwini N, Ramesh S, Nataraja K (2020) Assessment of DNA methylation pattern under drought stress using methylation-sensitive randomly amplified polymorphism analysis in rice. Plant Genet Resour-C 18:222-230. https://doi.org/10.1017/ S1479262120000234

Savvides A, Ali S, Tester M, Fotopoulos V (2016) Chemical priming of plants against multiple abiotic stresses: mission possible? Trends Plant Sci 21:329-340. https://doi.org/10.1016/j.tplants. 2015.11.003

Sen A, Puthur JT (2020) Seed priming-induced physiochemical and molecular events in plants coupled to abiotic stress tolerance: an overview. In: Hossain MA, Liu F, Burritt D, Fujita M, Huang $B$ (eds) Priming-mediated stress and cross-stress tolerance in crop plants. Elsevier, Amsterdam, pp 303-316. https://doi.org/ 10.1016/B978-0-12-817892-8.00018-0

Sharma P, Jha AB, Dubey RS, Pessarakli M (2012) Reactive oxygen species, oxidative damage, and antioxidative defense mechanism in plants under stressful conditions. J Bot 2012:217037. https:// doi.org/10.1155/2012/217037

Sher A, Sarwar T, Nawaz A, Ijaz M, Sattar A, Ahmad S (2019) Methods of seed priming. In: Hasanuzzaman M, Fotopoulos V (eds) Priming and pretreatment of seeds and seedlings. Springer, Singapore, pp 1-10. https://doi.org/10.1007/978-981-13-8625-1_1

Shinozaki K, Yamaguchi-Shinozaki K (2000) Molecular responses to dehydration and low temperature: differences and cross-talk between two stress signaling pathways. Curr Opin Plant Biol 3:217-223. https://doi.org/10.1016/S1369-5266(00)80068-0

Shukla N, Awasthi RP, Rawat L, Kumar J (2015) Seed biopriming with drought tolerant isolates of Trichoderma harzianum promote growth and drought tolerance in Triticum aestivum. Ann Appl Biol 166:171-182. https://doi.org/10.1111/aab.12160

Silva S, Santos C, Serodio J, Silva AM, Dias MC (2018) Physiological performance of drought-stressed olive plants when exposed to a combined heat-UV-B shock and after stress relief. Funct Plant Biol 45:1233-1240. https://doi.org/10.1071/FP18026

Sinclair BJ, Roberts SP (2005) Acclimation, shock and hardening in the cold. J Therm Biol 30:557-562. https://doi.org/10.1016/j. jtherbio.2005.07.002

Singhal RK, Kumar V, Bose B (2019) Improving the yield and yield attributes in wheat crop using seed priming under drought stress. J Pharmacogn Phytochem 8:214-220

Singroha G, Sharma P (2019) Epigenetic modifications in plants under abiotic stress. In: Meccariello R (ed) Epigenetics. IntechOpen, London, pp 1-14. https://doi.org/10.5772/intechopen.84455

Sun Y, Sun Y, Wang M, Li X, Guo X, Hu R, Ma J (2010) Effects of seed priming on germination and seedling growth of rice under water stress. Acta Agron Sin 36:1931-1940. https://doi.org/10. 1016/S1875-2780(09)60085-7

Sun RZ, Lin CT, Zhang XF, Duan LX, Qi XQ, Gong YH, Deng X (2018) Acclimation-induced metabolic reprogramming contributes to rapid desiccation tolerance acquisition in Boea hygrometrica. Environ Exp Bot 148:70-84. https://doi.org/10.1016/j. envexpbot.2018.01.008

Sun RZ, Liu J, Wang YY, Deng X (2021) DNA methylation-mediated modulation of rapid desiccation tolerance acquisition and dehydration stress memory in the resurrection plant Boea hygrometrica. PLoS Genet 17:e1009549. https://doi.org/10.1371/journal. pgen.1009549

Talbert PB, Henikoff S (2014) Environmental responses mediated by histone variants. Trends Cell Biol 24:642-650. https://doi.org/ 10.1016/j.tcb.2014.07.006

Tao Q, Lv Y, Mo Q, Bai M, Han Y, Wang Y (2018) Impacts of priming on seed germination and seedling emergence of Cleistogenes songorica under drought stress. Seed Sci Technol 46:239-257. https://doi.org/10.15258/sst.2018.46.2.06

Ueda M, Seki M (2020) Histone modifications form epigenetic regulatory networks to regulate abiotic stress response. Plant Physiol 182:15-26. https://doi.org/10.1104/pp.19.00988

Ulfat A, Majid SA, Hameed A (2017) Hormonal seed priming improves wheat (Triticum aestivum L.) field performance under drought and non-stress conditions. Pak J Bot 49:1239-1253

Virlouvet L, Fromm M (2015) Physiological and transcriptional memory in guard cells during repetitive dehydration stress. New Phytol 205:596-607. https://doi.org/10.1111/nph.13080

Vyse K, Faivre L, Romich M, Pagter M, Schubert D, Hincha DK, Zuther E (2020) Transcriptional and post-transcriptional regulation and transcriptional memory of chromatin regulators in response to low temperature. Front Plant Sci 11:39. https://doi. org/10.3389/fpls.2020.00039

Walter J, Nagy L, Hein R, Rascher U, Beierkuhnlein C, Willner E, Jentsch A (2011) Do plants remember drought? Hints towards a drought-memory in grasses. Environ Exp Bot 71:34-40. https:// doi.org/10.1016/j.envexpbot.2010.10.020 
Walter J, Jentsch A, Beierkuhnlein C, Kreyling J (2013) Ecological stress memory and cross stress tolerance in plants in the face of climate extremes. Environ Exp Bot 94:3-8. https://doi.org/10. 1016/j.envexpbot.2012.02.009

Wang WS, Pan YJ, Zhao XQ, Dwivedi D, Zhu LH, Ali J, Fu BY, Li ZK (2011) Drought-induced site-specific DNA methylation and its association with drought tolerance in rice (Oryza sativa L.). J Exp Bot 62:1951-1960. https://doi.org/10.1093/jxb/erq391

Wang X, Vignjevic M, Jiang D, Jacobsen S, Wollenweber B (2014) Improved tolerance to drought stress after anthesis due to priming before anthesis in wheat (Triticum aestivum L.) var. Vinjett $\mathbf{J}$ Exp Bot 65:6441-6456. https://doi.org/10.1093/jxb/eru362

Wang X, Vigjevic M, Liu F, Jacobsen S, Jiang D, Wollenweber B (2015) Drought priming at vegetative growth stages improves tolerance to drought and heat stresses occurring during grain filling in spring wheat. Plant Growth Regul 75:677-687. https:// doi.org/10.1007/s10725-014-9969-x

Widiez T, Symeonidi A, Luo C, Lam E, Lawton M, Rensing SA (2014) The chromatin landscape of the moss Physcomitrella patens and its dynamics during development and drought stress. Plant $\mathbf{J}$ 79:67-81. https://doi.org/10.1111/tpj.12542

Wojtyla $Ł$, Paluch-Lubawa E, Sobieszczuk-Nowicka E, Garnczarska M (2020) Drought stress memory and subsequent drought stress tolerance in plants. In: Hossain MA, Liu F, Burritt D, Fujita M, Huang B (eds) Priming-mediated stress and cross-stress tolerance in crop plants. Elsevier, Amsterdam, pp 115-131. https://doi.org/ 10.1016/B978-0-12-817892-8.00007-6

Yousefi S, Kartoolinejad D, Naghdi R (2017) Effects of priming with multi-walled carbon nanotubes on seed physiological characteristics of Hopbush (Dodonaeaviscosa L.) under drought stress. Int J Environ Stud 74:528-539. https://doi.org/10.1080/00207 233.2017.1325627

Zentner GE, Henikoff S (2013) Regulation of nucleosome dynamics by histone modifications. Nat Struct Mol Biol 20:259-266. https:// doi.org/10.1038/nsmb. 2470
Zhang X, Shen L, Li F, Meng D, Sheng J (2013) Arginase induction by heat treatment contributes to amelioration of chilling injury and activation of antioxidant enzymes in tomato fruit. Postharvest Biol Tec 79:1-8. https://doi.org/10.1016/j.postharvbio.2012.12. 019

Zhang X, Wang X, Zhong J, Zhou Q, Wang X, Cai J, Dai T, Cao W, Jiang D (2016) Drought priming induces thermo-tolerance to post-anthesis high-temperature in offspring of winter wheat. Environ Exp Bot 127:26-36. https://doi.org/10.1016/j.envexpbot. 2016.03.004

Zhang X, Wang X, Zhuang L, Gao Y, Huang B (2019a) Abscisic acid mediation of drought priming-enhanced heat tolerance in tall fescue (Festuca arundinacea) and Arabidopsis. Physiol Plantarum 167:488-501. https://doi.org/10.1111/ppl.12975

Zhang X, Xu Y, Huang B (2019b) Lipidomic reprogramming associated with drought stress priming-enhanced heat tolerance in tall fescue (Festuca arundinacea). Plant Cell Environ 42:947-958. https://doi.org/10.1111/pce.13405

Zhu Y, Wang B, Phillips J, Zhang ZN, Du H, Xu T, Huang LC, Zhang XF, Xu GH, Li WH, Wang Z, Wang L, Liu YX, Deng X (2015) Global transcriptome analysis reveals acclimation-primed processes involved in the acquisition of desiccation tolerance in Boea hygrometrica. Plant Cell Physiol 56:1429-1441. https:// doi.org/10.1093/pcp/pcv059

Publisher's Note Springer Nature remains neutral with regard to jurisdictional claims in published maps and institutional affiliations. 